\title{
ARCHITECTURAL DEVELOPMENT OF HISTORIC HEALTH CARE INSTITUTIONS IN VILNIUS CITY
}

\author{
Gintaras Stauskis \\ Dept of Urban Design, Vilnius Gediminas Technical University, \\ Pylimo g. 26/Trakug. 1, 01132 Vilnius, Lithuania \\ E-mail: Gintaras.stauskis@ar.vgtu.lt
}

Submitted 18 Jan. 2010

\begin{abstract}
For centuries health institutions have been the most traditional community-oriented providers of public services. The paper focuses on the initial steps of urban development of health facilities in Vilnius city. Historic health institutions are analysed as a specific prototype of what is understood today as a "hospital". In the paper special attention is drawn to the process of emerging of "a hospital" as an independent public institution, its connections to other public buildings, its urban integrity with adjusting and surrounding development as well as its architectural importance for Vilnius city.

Having emerged as a consistent part of religious and sacral complexes, health institutions (špitolès - in Lithuanian) occupied a part of space in traditional convents, located throughout Vilnius Old Town. In early years (around the 15th-16th c) health and treatment spaces were based in ordinary rooms of convents and monasteries. Later in the 17th-18th c they were transferred to specially designated blocks and houses within a convent territory and occupied a major part of spaces there. In the late 18th -18 th c health facilities gradually were disconnected from convents and churches to separate building complexes and finally became completely a new and independent type of public institutions.

During the historical periods of development health complexes changed their functional layout and so their planning from initial missions of "separation" and "isolation" to "care" and developed finally to "healing" and "cure". Analysis of selected cases in Vilnius Old Town reveals that as long as changes in urban location of health complexes took place, it was followed by their functional evolution. Making an integral part in numerous sacral complexes, usually consisting of a church, convent, healing centre, garden and cemetery, health institutions were a part of important "architectural hills" that are clearly notable as vertical and spatial landmarks in the surrounding townscape of Vilnius city. Artistic spatial arrangement and architectural expression are the other specific traits that distinguish health complexes - hospitals - in the context of surrounding development.

Health complexes have always played the most important public role in Vilnius city as centres of social aid, community life, religion, culture and health services for local neighbourhoods. Research on the development of health institutions in historical run is a strong foundation to build up the perspectives for architectural and municipal policies for the future of these complexes. The issue gains special importance in the recent situation of essential transformation of the public health care system in Lithuania and in Vilnius city.
\end{abstract}

Keywords: urban planning, health institution architecture, social aid, skyline, landscape, functional structure, composition, hospital.

"Little as we know about the way in which we are affected by form, by colour, and light, we do know this, that they have an actual physical effect". Florence Nightingale (1860:58)

\section{Introduction}

These inspiring words from one and a half century old times give us a good spirit to initiate analysis of historical development of health institutions in modern urban landscapes. The word "hospital" clearly derives itself from the meaning of hospitality and hospitability which carries the very initial meaning of a refuge space for sick persons. In many languages nowadays it bares quite a different meaning, sometimes associated not so much with health but more with sickness: ("ligoninë"- in Lithuanian, "sjukhus" - in Swedish, "krankenhaus" - in German) or a "pain place" ("bolnica" - Russian). This is certainly just a verbal charac- 
teristic of a hospital of the 19th $\mathrm{c}$ but not the original social meaning of the institution, deriving itself from the need to take care, cure and protect.

Since the early times health and other social care institutions have been the main providers of social services for the residents of towns and cities. Devoted staff was running premises of different size, location and quality but by all possible means providing the needed shelter, care and cure for the members of local community. The attractive and teaching historical retrospective gives us a chance to analyse the primary steps of development of what is understood today as a modern "hospital". And not just for the sake of an academic exercise but for serious practical applications as well. The concept of modern health care system, especially the functional arrangement and scope of services provided by hospitals in Lithuania, is in a deep and continuing crisis and so is undergoing a radical transformation. (Stauskis 2005: 41-46). In spite of consuming a considerable part of public resources, social and health care institutions have gradually lost their contact with the public, neighbourhoods and the surrounding city. Unfortunately, exactly these were the initial goals that health care was created centuries ago. Lithuania could serve as a rather typical case where hospitals became isolated "medical factories" of sickness located on remote lands and fenced from the public of its town. Their urban inclusion vanished and their architecture could hardly be attributed to the field of art. For these reasons the need to find new ways of further re-development of our hospitals is very up-to-date. The author of this paper hopes that the history of urban development of hospitals in Vilnius city could serve as a deep resource of ideas for social inclusion, urban integration, functional and compositional re-arrangement of modern health complexes that could gradually bring back confidence of the public in hospitals and health care. The aspect of relationship between different types of development in urban context is a strong challenge for hospitals as underlined by Gordon Cullen in his famous book "The Concise Townscape" (Cullen 1990: 78).

\section{The goal and objectives of investigation}

Being performed in the urban context of Vilnius city the presented analysis focuses on evolution of modern health facilities from the earliest stages that were disclosed through the periods of development and to a time when a hospital is identified as an independent social care facility in the town structure. The paper draws conclusions on historical periods of develo- pment of health institutions in Vilnius city, also on the important lessons of history that might be learned and applied for re-structuring of health care network in general and hospital as a social institution in particular. The analysis is performed on the ground of Vilnius city, but the methodical lines of study as well as the conclusions are applicable to all big Lithuanian cities, also those in the neighbouring regions.

The importance of health complexes in urban architecture is in the focus of investigation. The goal is disclosed by presenting historic analysis of the development of health facilities in the city during different periods of evolution of Vilnius Old Town, also by presenting urban analysis of architectural complexes where the first health institutions have emerged.

The resources of archives and other written, printed and iconographic material were analysed as an important method of investigation. This allows collecting sufficient material and drawing the conclusion. Comparative analysis of different health complexes in the historic environment allows to define the periods of development of these public health service providers.

The process of development of health care complexes until the typology of a modern hospital became clearly identified is important in order to draw parallels between modern health complexes and their historic predecessors. In many cases penetrating back to the roots provides for us a possibility to create a perspective from the past through today and to the future. Today hospitals and the whole health sector in Lithuania are once more facing the most radical transformations, and a new look into the future might be based on better understanding of the past.

\section{Care \& Cure functions emerging in Vilnius historic health complexes}

Emerging of health institutions as a prototype of a hospital was based on radical needs of society. The need of isolation and concentration of sick patients appeared for two main reasons - firstly, the need to isolate urban community from infected persons and so to prevent diseases from spreading into a wider community, and, secondly, to isolate sick people bearing viruses and infections of a different type and stop local spread of diseases. Physical isolation and separation might be considered to be quite a primitive healing principle but until the present days it is one of the most effective methods.

In the face of spreading infections, diseases and wars the need to isolate sick residents and tenants undoubte- 
dly was an evident need, and it became an initial reason for sheltering the sick from the rest of a neighbourhood and the whole community. Convents and monasteries fitted for this in the best way. Consequently, some part of their space was assigned just for sick, infected or wounded persons. This space assignment was temporary at the beginning, later it became permanent and was accessed mainly by the caring staff. Care of the sick was the basic and for a long period of time the only service in historic health centres. These spaces were isolated from the rest of a complex, and a quarantine regime was an effective way to stop a disease or infection from spreading into the wider community.

Gradually it was noticed that just passive care was not sufficient enough in order to make the health of tenants improve. Different methods of curing patients were started in addition to a passive care. From different written sources we can guess those being mainly the ones of a traditional or the so-called "folk medicine", including physical procedures as hot bath and sauna, different body massages and other physical exercises, exterior and interior herbal treatments, and so on.

Rapid development of sciences took place in Europe and so universities and other academic centres were established in many European cities. After establishing the University in 1579 , Vilnius city was among the strongest educational and research centres in Europe of that time. This was followed by more rapid development of health-related sciences as chemistry, biology, physics and medicine. At that time the first Department of Medicine (Collegium Medicum Vilnensis) was established in Vilnius city. It was initially located outside Vilnius University complex and based on Didžioji str. (see point 8 in Fig. 1) because of still quite reserved attitudes of authorities towards medical practices and methods.

As long as the related sciences were developing in the middle of the 19th $\mathrm{c}$ and new curing methods appeared gradually the scope of medical services was broadening, the number of treated diseases was extending,

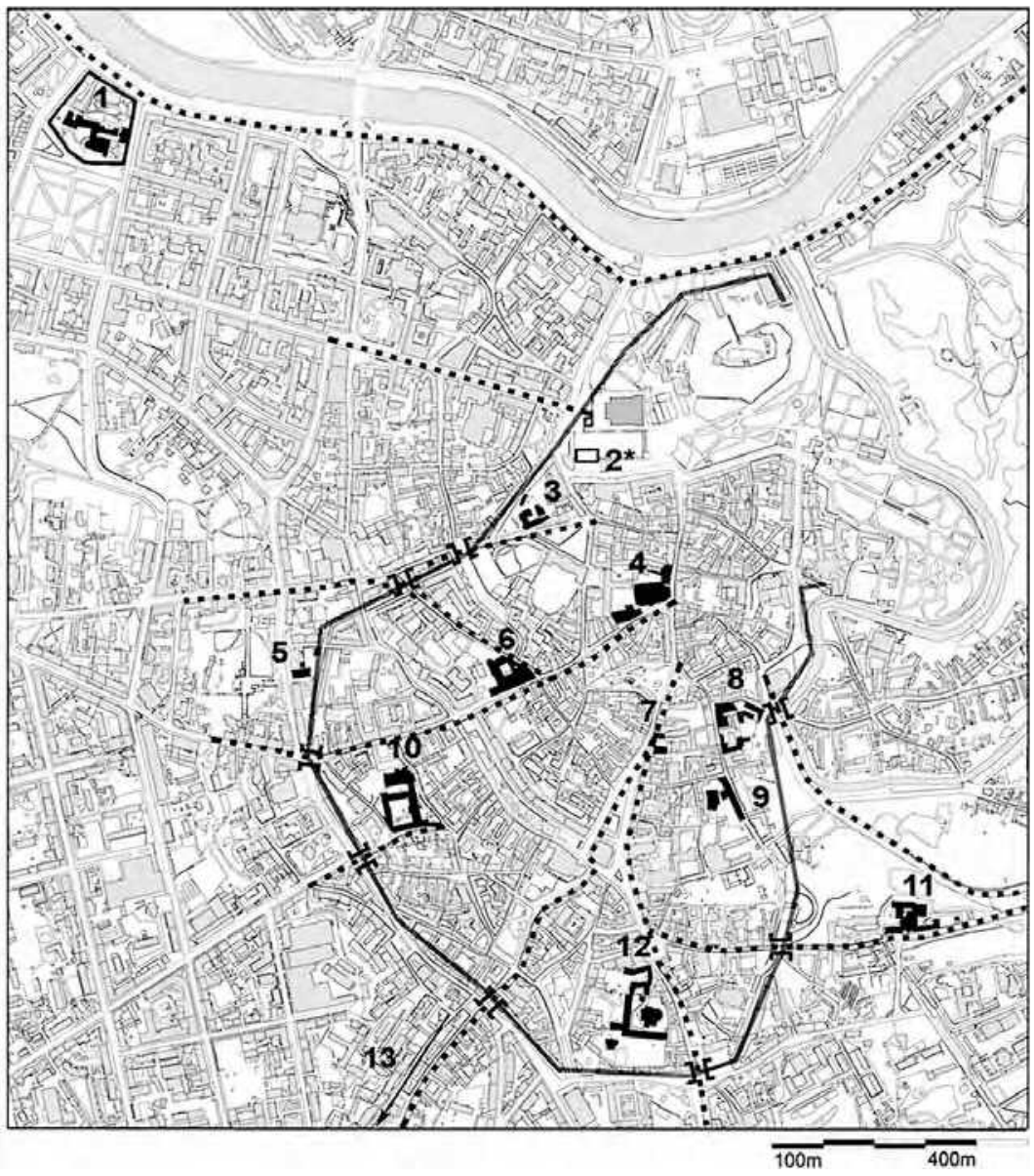

Fig. 1. Location of healing institutions in sacral objects of Vilnius Old Town in the 16th-19th c
1. Healing centre at St. Jacob and St. Philip Convent and the Church on Goštautas Street (1731)

2. The first healing centre in Vilnius and Lithuania by the Gates of Maria Magdalene (1510-1518, 12 beds), demolished*

3. Healing centre for mental patients at the Convent of Bonifrates on L. Gucevičius Street (1636)

4. TheFaculty of Medicine in Vilnius University (1781-1939)

5. Healing centre next to Reformat Church on Pylimas Street (1580)

6. Healing centre at St. Dominican Convent on Dominikonai Street (1536)

7. The Department of Medicine in Vilnius University on Pilis Street (1775)

8. Healing centre next to St. Spaso Church on Maironis Street (1560)

9. Healing centre of The Merciful Sisters on Savičius Street (1744, 150-200 beds)

10. Hospital for soldiers next to The Convent of Franciscans on Pranciškonai Street (1831-1837)

11. War hospital at Missionary Convent and Church on Subačius Street (1812-1817)

12. St. Trinity Healing Centre at Bazillion Convent on Aušros Vartai Street (1536, 70 beds)

13. St. Lazarus Healing Centre next to St. Stephanie Church on St. Steponas Street (1600) 
but because of the costs health services were mainly affordable for the noble and the rich.

\section{Establishment and development of health institutions in Vilnius}

The first spaces assigned for health services in Vilnius were located inside sacral institutions - convents and monasteries. The complexes of sacral buildings were usually situated on separately controlled land plots in the centre or in a periphery of the town. Depending on the locations convents usually had more or less extended private gardens and a complex of sacral, residential and supplementary buildings. In Vilnius city which in the time of its prosperity in the 15th-16th c had more than one hundred churches and convents, a complex usually consisted of a church that served for monks and nuns, also for a local parish, a convent or monastery, where nuns or monks resided, supplementary technical buildings as storages and workshops, and a park with a garden that served as a place of daily promenades and when enough of land was available also as a fruit and vegetable producer. Usually a cemetery was also a constituent part of the whole complex. Planning and the overall structure of complexes were changing in different urban locations. It ranged from perimeter block-type planning in situations of development along the main streets (Bonifrates complex in Fig. 2.1; also Missionaries complex), to centre-designed planning on more big plots (Bazillion complex in Fig. 2.2) and finally to free-type planning in Vilnius suburbs of that time (St. Jacob and Philip complex in Fig. 2.3).

In Vilnius urban centre land was costly, therefore properties were smaller and surrounded by dense neighbouring development. Therefore, pieces of an un-built open space were quite small. Consequently, the buildings formed dense blocks and rows around the plot borders or possession lines and the city streets with small yet cosy interior courtyards and incorporated gardens.

When these healing spaces were moved out of common residential buildings and transferred into specially assigned blocks at the end of the 18th $\mathrm{c}$ - beginning of the 19th c, healing, caring and curing functions occupied already a larger space - up to a half of the designated buildings.

The next phase of development of historic hospitals in Vilnius city led to further separation of health premises from convents and monasteries and to establishment of an autonomous community-oriented health and care institution. Being more and more connec- ted to the surrounding urban community by providing it with wider and more diverse health and other social services as shelter, food, care and cure, health institutions were losing their close ties with convents and gradually were gaining more contacts with Vilnius city and its community. This process ended with complete separation of health facilities from religious convents and parishes and appearance of independent health complexes where health functions usually occupied up to $100 \%$ of their building space. It is observed that a good location on the main streets with direct access from the city centre to the periphery was critical in this process. E.g. the first real city hospital since $1699-$ St. Jacob and Philip Hospital - was based in an extremely comfortable logistical location.

On the outskirts and suburbs of Vilnius, where larger land plots were available and surrounding development was scarce, the monasteries and similar religious complexes were planned quite extensively with a larger open space and greater distances between different buildings (see Fig. 2.3). Because of weaker contacts with Vilnius community and a poor chance to provide it with any social service, health premises in these facilities for a long time remained mainly a place to take care of their own tenants and some local residents from surrounding suburban villages.

It could be noted that in Vilnius city the process of separation of health complexes from convents and establishment as independent public institutions was happening later than in the other cities of Europe where the first independent city hospitals were established in the 17th-18th c. (Kjisik 2009: 22-28).

\section{Network of historic hospitals in Vilnius Old Town}

This chapter reveals the character of location of traditional health care complexes in the territory of Vilnius Old Town as shown in Fig. 1. The door of the first health and care house was opened in Vilnius in 1514 on Šventaragis Street opposite the Cathedral Square and the Lower Castle Complex (Biziulevičius 1983: 36) (point 3 in Fig. 1) by Martynas from Dušnikai, the personal physician of the Lithuanian Grand Duke Alexander (M. Budriené 1991: 300-307). Selection of the main public square situated near the main streets of Vilnius of those days shows particular importance for location of this complex.

The order of Samogitian Bishopric Synod from 1651 (Šeimos ... 2009) to establish health units (špitolès - in Lithuanian) next to churches in local parishes was soon 


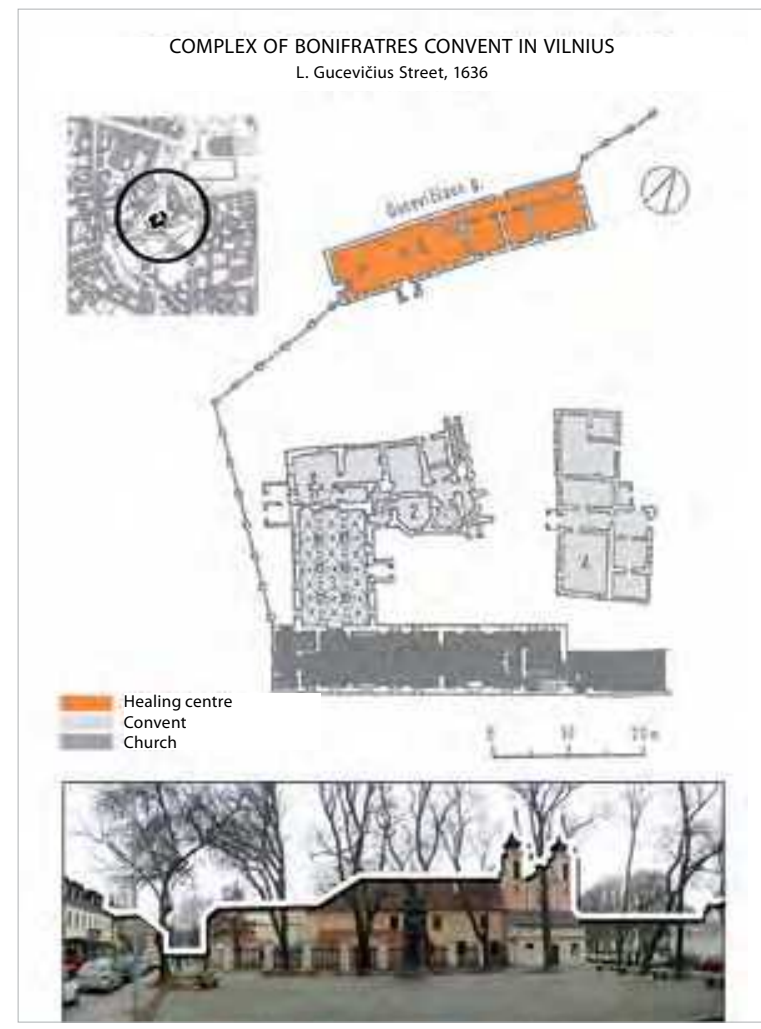

2.1.

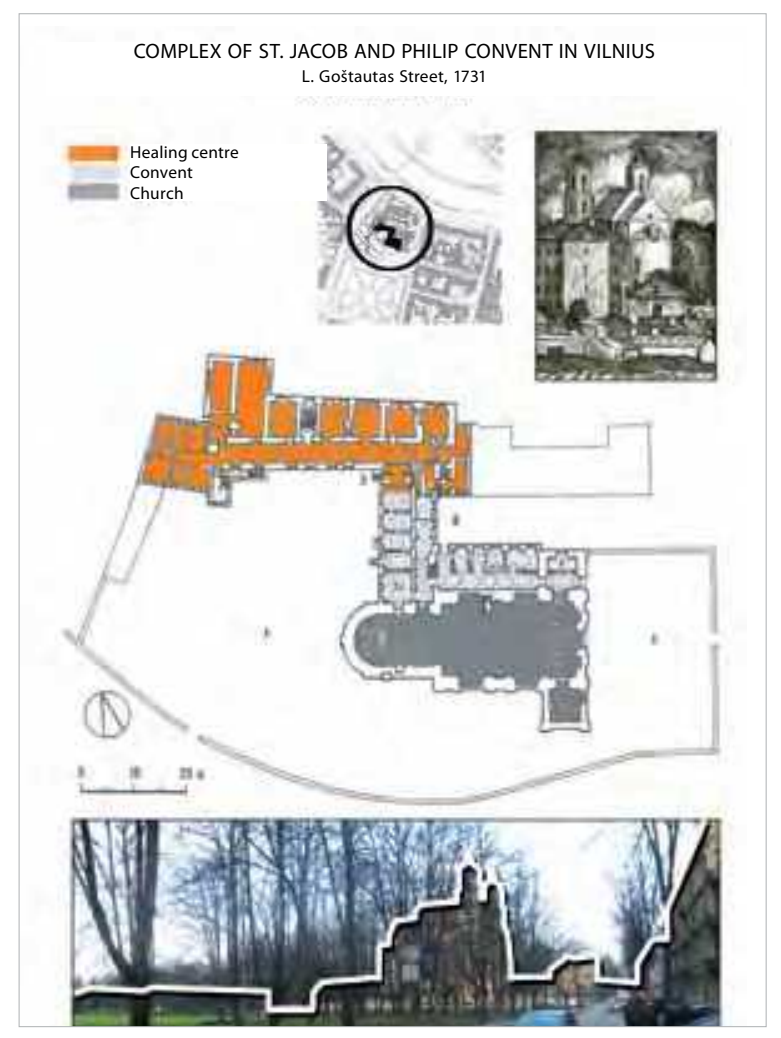

2.3.

Fig. 2. Historic healing institutions in sacral complexes of Vilnius city

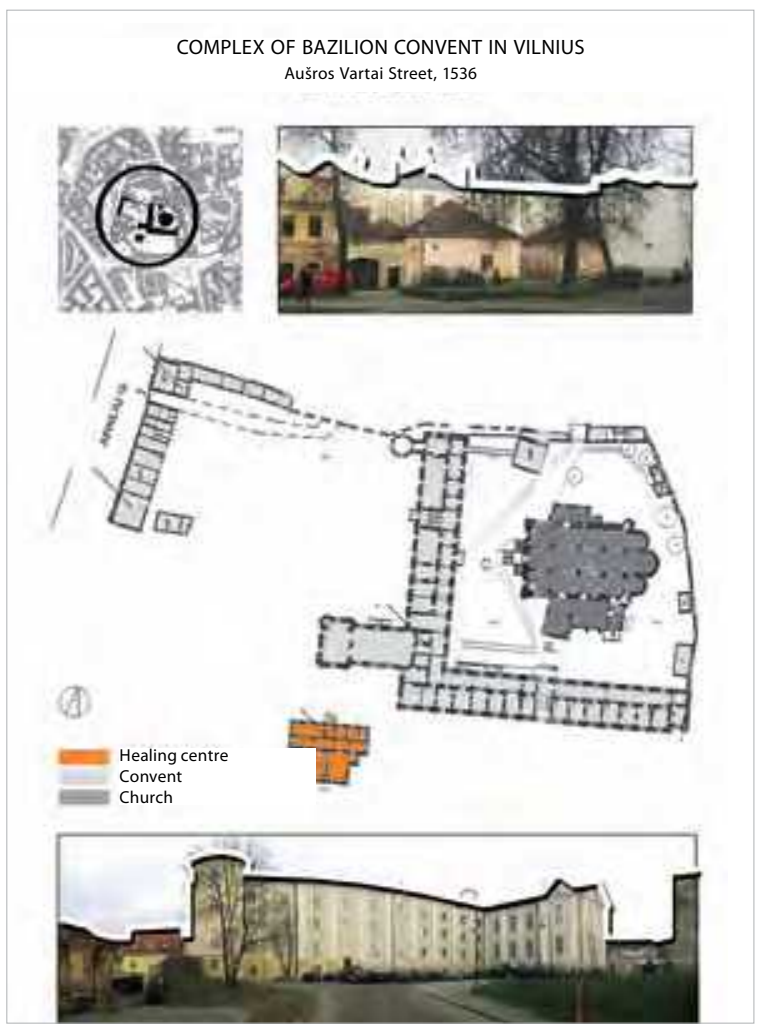

2.2 .

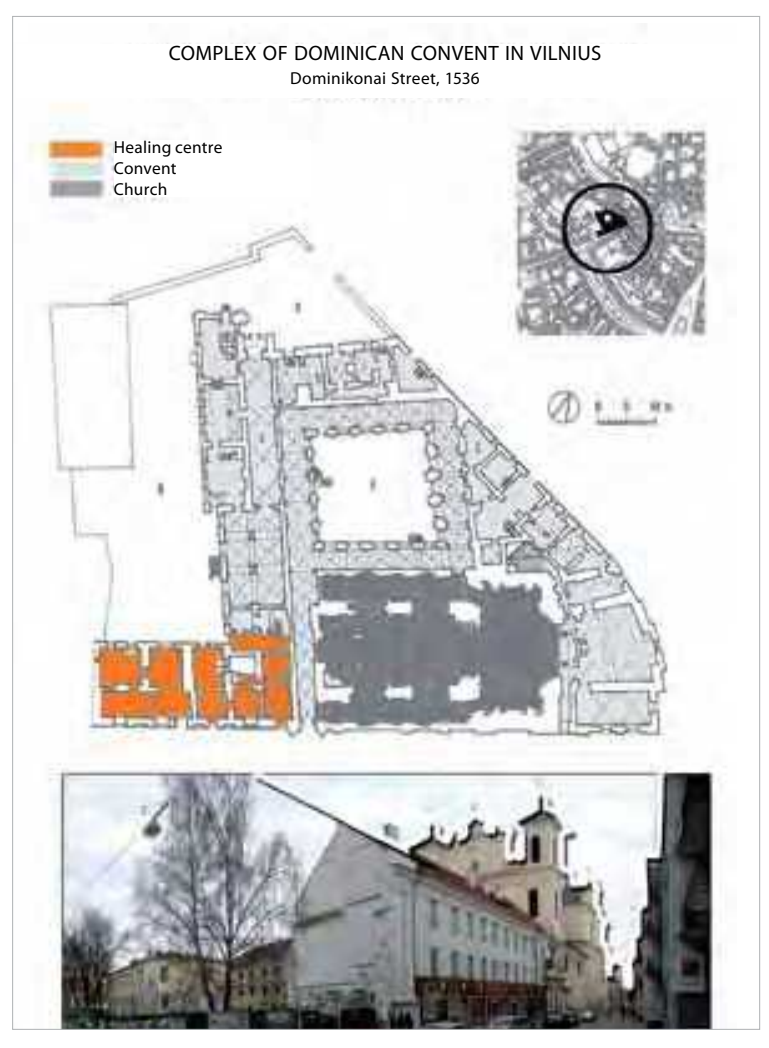

2.4. 
taken over by the authorities of Vilnius city churches, and the majority of convents and church complexes in Vilnius established their own health units. In quite a short period of time a dense and well-developed network of informal health care complexes was established in Vilnius: health facilities were well distributed in the town area, located in short distances as resident access to almost all of them was in less than 200-250 metres or 5-7 minutes of walking time.

As we definitely know, each church had its parish or vice-versa we can say each local neighbourhood had a church. In other words, location of church and convent complexes reveals the network of parishes and their ruling churches. The group of residents that belonged to a single parish was in a constant contact with a church and a convent for different reasons of interest. Most probably care and health were also among them.

For the sake of the investigation it is important to notice a connection between the location of sacral complexes and the structure of local neighbourhoods in Vilnius Old Town. In that situation health complexes logically were providing service just for a certain number of local residents in their intake areas. According to the map of sacral sites with identified health complexes located in Vilnius convents, it is evident that these intake areas were quite small, distances were short and that means that a perfect access to health care service of available type was provided for the residents of Vilnius Old Town. This system could be clearly attributed to the prototype of primary health care network.

Another important note on the location of health institutions that could be called predecessors of city "hospitals" is that almost all of them are located on the main city streets, leading in and out of the city through the historic city gates. As it is evident in Fig. 1 these are Gediminas street and the Lower Castle area (the first healing centre No. 2), Goštautas str. (healing centre No. 1), Dominikonai - Trakai str. (healing centres No. 4, 6, 10), Aušros Vartai str. (healing centre No. 12), Subačius str. (healing centres No. 8, 9, 11) and others. All the named city streets (given here as they appear today) constitute an important axis leading from the outskirts directly to the city center and vice versa. This brings us to another important observation that a good logistical position of healing centres was considered to be important even in the early stages of development of early healing centres in Vilnius.

The network of primary healing centres was scattered throughout the convents of Vilnius city until the very end of the 18th c. In 1799 by the decision of Vilnius City Hall the first city hospital was established on the basis of already existing health centre at St. Jacob and Philip Convent (Firkovičius 1989: 27) (see point 1 in Fig. 1). A new era of development began when healing and caring resources were concentrated from many small units into one city hospital. For a period of time the larger of the former convent hospitals remained open (St. Dominican, St. Nicodemus, St. Peter), and some of them later became important health objects as hospitals in Vilnius city.

There is one more side of extraordinary importance in this investigation. While being worth a special extensive analysis it still deserves a brief mention here for the sake of completeness. It is well known from different archival sources and researches of selected authors (J. A. Dainauskas 1997, D. Petrauskaite 2006) that sites for locating sacral complexes and churches were always selected based on more important aspects than just good locations and nice views. Places of positive geological bio-energy with pure water sources were the main objectives for selecting sites for important buildings. Methods of discovering the natural geological energy of a site had been well known and widely applied already many centuries ago. In research works of the 19th and 20th centuries this system was named as positive ("Schumann") and negative ("Hartmann") interchangeable grids with special intersection points. The basic and more sophisticated methods of creating architectural shapes and volumes could be accessed from numerous bio-geometry research and practice resources (Architecture 2003). It is well known that the principles of radiesthesy (I. Karim 2006) were widely used for therapeutic reasons while selecting the sites and the environment, planning and constructing any type of architectural complexes especially those related to healing and health services. Importance of this aspect nowadays is clearly underestimated though healing qualities of sacral and health care sites are strongly outlined by modern health environment researchers (Rechel et al. 2009: 233-236).

There is a strong belief that all the historic sacral complexes in Vilnius city were established, designed and constructed with the deepest knowledge of specific features of the sites: negative and pathogenic gridlines and intersections were avoided and positive beneficial lines and points were used for development of buildings. Health complexes taking their start in historic convents of Vilnius city most naturally used all the benefits of their energy-positive locations on geological energy grids. The typical way was to use peculiarities of terrain and relief, also have proximity to clean waters as springs and rivers. It is clearly shown in Fig. 1: the first 
healing centre on Šventaragis Street at the Cathedral Square was constructed on the bank of the former Vilnia river branch (point 3 in Fig. 1); the Missionaries Convent was erected on a high slope that had fresh water springs filling the ponds below (point 13); healing centre nearby Spaso Orthodox Church (point 9) located on the banks of pure waters of the Vilnia river; even the St. Jacob and Philip Convent (point 1) had the Neris river at its feet. This is one more admirably wise application of powerful healing values of rich Vilnius nature by locating health institutions near water sources to get the biggest healing benefits for the patients.

\section{Compositional features of sacral complexes with integrated health institutions}

Location of sacral complexes in Vilnius Old Town results in very specific outlooks created by decent application of several compositional effects. They are based on carefully selected special places and land plots that usually appear on higher and well-observed city locations with the most spectacular outlooks and so vertical and spatial dominants become clearly visible in city skylines and panoramas. The volumes of convents that are usually smaller and lower than those of churches still strongly dominate in the whole complex and are visible in the city roofscapes and panoramas.

Importance of variety of views, objects and colours on sick people was underlined by Florence Nightingale, the first nurse who in 1860 in a purely comprehensive way described how the environment for the sick needs to be arranged and managed (Florence Nightingale 1860: 58-63). It is reasonable to believe that while selecting location of spaces for health care facilities in Vilnius these principles were strongly obeyed.

Sacral complexes are always carefully integrated into the surrounding urban development. Each city and country has its own specific typology of spatial and volumetric solutions on how to arrange relations between sacral buildings and other neighbouring development into one urban net. The topic has been extensively discussed and artistically depicted by Camillo Sitte in his brilliant publication on artistic principles of urban design (Sitte 1889: 85-129). Many of the described characteristic features also apply to Vilnius city of the 16th-19th centuries. The most prominent methods used in Vilnius are creating inbuilt architectural complexes, row-blocked perimeter development and free-type development with a variety of public spaces as squares, gardens and parks around. The analysis performed reveals several characteristic types of such an integration:
- The main building - a church - is heavily inbuilt into the surrounding convent shape with health spaces and open to the street space just by one main façade along with convent volumes (Missionaries Church and the convent - point 11 in Fig. 1);

- The same case when a church opens to the street space by a side façade with adjusting convent walls (St. Dominican Convent and the church - Fig. 2.4);

- Blocks of a convent surround the main church building from three or more sides and the church appears inside a local space in the central courtyard (Bazillion Church and the convent - Fig. 2.2). In this case the local view of the complex is quite poor but it appears actively in more remote panoramas and city skyline;

- The church building is dominating in a local space and just adjoins to the convent building with integrated healing spaces by one or two walls (Bonifrates Convent complex - Fig. 2.1, St. Jacob and Philip Convent complex - Fig. 2.3, Franciscan Convent complex point 10 in Fig. 1) (Paminklų ... 1989:27). Also, some mixed or complex cases could be distinguished.

Indeed in all of the analysed sacral complexes a dominating role is clearly and understandably given to a church building with one or two symmetrical or asymmetrical towers or imposing frontons, more distinguished volumes and architectural elaboration. The residential blocks of convents nevertheless are spatially very significant in the composition of all the complexes and play a secondary but clearly expressed volumetric role (Figs. 2.1, 2.2, 2.4) that distinguishes them from ordinary perimeter development of an urban block. The more inbuilt into surrounding development appears a church volume, the more important role is given to convent blocks and buildings with incorporated health care facilities.

\section{Health complexes in the cultural landscape of Vilnius city}

Through all the periods of evolution health institutions have strongly affected the development of urban landscape of Vilnius city as they were located on important shapes of terrains, groups of green plantings were usually included into their planning structure which was composed around different types of public, semiprivate and private spaces.

In Vilnius city a special charm is achieved by artistic mixing of architecture with landscape masses and 
elements. By this method building complexes appear in a certain scale dimension, also it softens and solutes the dense urban development with green plant inclusions, and distinguished volumes of sacral buildings appear more notably in urban townscape on a green background. Cultural parks and gardens of convents, where health facilities took their start, join to the natural system of green plantings together with the surrounding city parks and so enrich and dignify the landscape of Vilnius Old Town.

The essential compositional character of health and sacral complexes in the landscape of Vilnius city is determined by extremely masterly selected locations. All the churches and adjoining convents with health blocks are located on carefully selected land plots: the areas are in extraordinary influential points in the city because of good vertical exposition on slopes of the Old Town. Health and sacral complexes have also been established on the most important nodes of the city meaning crossings and spaces along the main city streets - see examples on the map in Fig. 1. Volumes and verticals of these complexes marked the edges of spaces and up till now are the strongest landmarks in Vilnius Old Town.

The green volumes located in these complexes played different roles in the landscape of Vilnius Old Town. Firstly, the green islands of interior gardens were adjoined to the urban and suburban forest masses thus connecting buildings to the surrounding green masses. Secondly, the green spaces of convents and hospitals were often located on greenways leading from the city centre to the outskirts and in this way becoming joining and filling elements on these lines. The Missionaries Church and Convent illustrates this case quite well (point 11 in Fig. 1). Another type of role - a central element of green public space in quite a densely built up urban context as at Bazillion Convent complex (point 12 in Fig. 1). In this way groups of plantings make a strong impact on the visual and spatial character of landscape in Vilnius Old Town.

It is important to underline that open-air facilities as gardens and parks along with the ecological qualities of the surrounding environment were always considered as the most important healing elements of the whole healing process. Therefore, the role of landscape and planting system for a healing environment could hardly be overestimated.

The location of a garden is an important element noticed in most of religious complexes. The whole complex consists at least of a church and a convent and being located even on the smallest available land plot it always included space for a garden (see Figs. 2.1 -2.4). Sometimes this green open space was developed on a really tiny piece of plot that was specially kept free. This specific trait is indeed quite common for the urban landscape of Vilnius city, where even in the densest downtown locations with small land plots and intensive neighbouring development suddenly groups of green plantings - different types of trees, bushes and shrubs appear offering the most picturesque landscapes and spectacular views of an architectural environment in the Old Town of Vilnius (Fig. 3). It is worth mentioning that groups of trees and buildings are on a similar scale: the height of a grown tree equals about that of a threestorey house.

\section{Conclusions}

Analysis of the objectives of the performed investigation opens a possibility to draw the following conclusions:

1. Historically healing service providing institutions in Vilnius city have emerged at religious institutions - complexes of convents, monasteries and churches. As long as their scope of services and size was increasing because of more patients attracted they

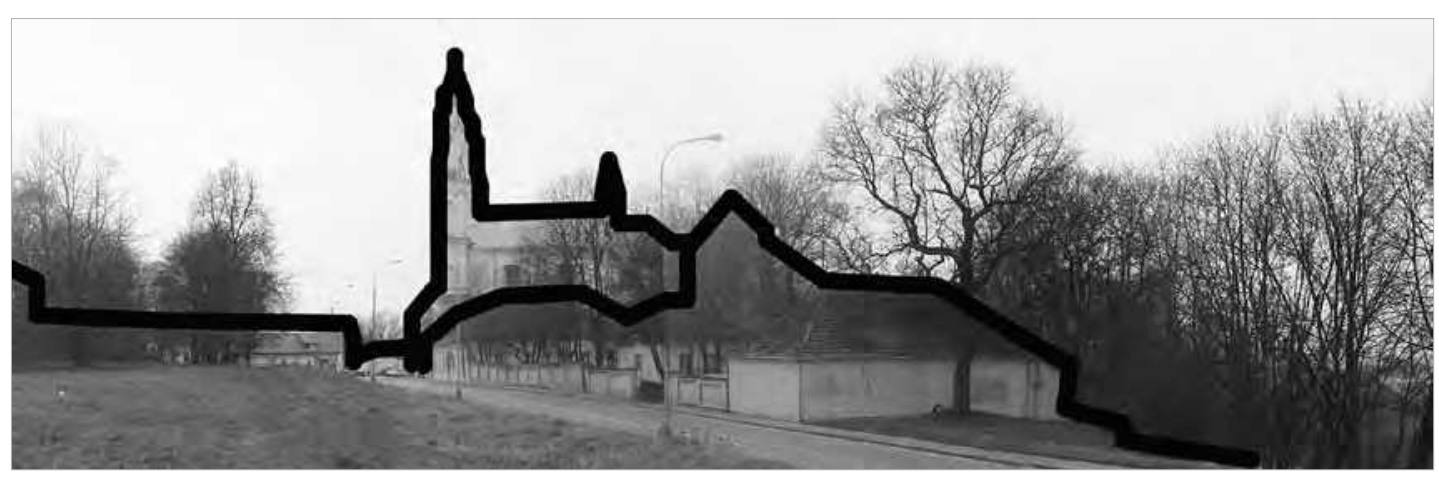

Fig. 3. Skyline of Missionaries Church and the convent in Vilnius 
were gradually separating from religious complexes and establishing themselves as public health service providing institutions - hospitals.

2. Healing institutions from the early years of development were always very closely integrated with local communities and neighbourhoods (parishes). The network of location of historic healing centres corresponds to the structure of traditional local communities in Vilnius city.

3. In the city architecture healing centres appeared incorporated in the architectural complexes of convents and churches with important landscape elements and became significant architectural landmarks of Vilnius city with special sites of location, dominating volumes and architectural elaboration of their buildings and important green volumes. All this makes health complexes important architectural elements forming the character of Vilnius cityscape that has a great heritage value.

4. Having separated from religious complexes in late 18th-19th c, health complexes became a new significant type of a public institution. It has developed its own functional and planning structure and specific compositional impact that it had for centuries on the urban architecture of Vilnius city. Simultaneously it was gradually widening and spreading its ties to local communities and neighbourhoods.

5. Historical evolution of health-care complexes could serve asa lesson of urban, architectural and social consciousness for modern health care. Urban inclusion, functional and spatial integration as well as developed social contacts should be considered to be the key principles for transforming the hospitals and the whole health-care sector in Vilnius city.

\section{References}

Architecture. 2003 [interaktyvus] [žiūrèta 201001 18]. Prieiga per internetą: $<$ http://users.telenet.be/wouterhagens/biogeometry/architectuur_uk.html>.

Biziulevičius, S. 1983. Vilniaus ligoninių genezè, Sveikatos apsauga 1: 36 .

Budrienė, M. 1991. Medicinos išsivystymo raida Lietuvoje XV-XX šimtmečiuose, Aidai [interaktyvus] 4: 300-307 [žiūrèta 201001 18]. Prieiga per internetą: <http://www. aidai.us/index.php?option=com_content $\&$ task=view\&id $=$ 7963\&Itemid=502>

Cullen, G. 1990. The Concise Townscape. ISBN 0-85139-568-6.

Dainauskas, J. A. 1997. Energetical - Networking Structure of Earth is Homeostatic Information Flow. Kaunas: Kaunas University of Technology.
Karim, I. 2006. What is Radiesthesia? [interaktyvus] [žiūrèta 201001 18]. Prieiga per internetą: <http://users.telenet.be/ wouterhagens/biogeometry/whatisradies_nl.html>.

Firkovičius, R. 1989. Paminklu konservavimo institutas. Kulto pastatai ir jų vietos Vilniaus mieste. Katalikų bažnyčiu istorijos apybraižos. Istoriniai tyrimai. Archyvas. Vilnius. Byla F5 5563, p. 27.

Florence Nightingale. Notes on Nursing. 1860. New York, D. Appleton and Company.

Kjisik, H. 2009. The Power of Architecture. Towards Better Hospital Buildings. Helsinki University of Technology. Helsinki. ISBN 978-952-248-033-0.

Petrauskaitè, D. 2006. Biolokacija [Biolocation]. Panevėžys.

Rechel, B., et al. 2009. Investing in the Hospitals of the Future. European Observatory on Health Systems and Policies. World Health Organisation. ISBN 9789289043045.

Šeimos sveikatos enciklopedija [interaktyvus]. 2009 [žiūrèta 201001 18]. Prieiga per internetą: <http://www.emarkt.lt/ products/autoriu_kolektyvas_seimos_sveikatos_enciklopedija/(parent_node)/4122/(myoffset)/>.

Sitte, C. 1889. Der Staedtebau nach seinen kunstlerische Grundsaetzen. Wien.

Stauskis, G. 2005. Optimization of Urban Planning Model for Developing Health Care Network in Vilnius Regional Area, Urbanistika ir architektūra [Town planning and Architecture] XXIX (1): 41-46.

Vilniaus Universiteto medicinos fakultetas [interaktyvus] [žiūrèta 201001 18]. Prieiga per internetą: <http:// lt.wikipedia.org/wiki/VU_Medicinos_fakultetas>.

\section{ISTORINIŲ SVEIKATOS PRIEŽIŪROS OBJEKTŲ ARCHITEKTŪRINĖ RAIDA VILNIAUS MIESTE}

\section{G. Stauskis}

Santrauka. Straipsnyje pateikiama sveikatos priežiūros ìstaigu - šiandienos ligoninių prototipo - urbanistinės raidos analizè istoriniu rakursu. Atskleidžiama pirmųjų sveikatos priežiūros objektų - gydyklų - raidos chronologija išryškina jų ryšius su kitais visuomeniniais kompleksais, jungtis su gretimu ir aplinkiniu miesto apstatymu, taip pat architektūrinę svarbą Vilniaus miestui.

Atsiradę po Vilniaus senamiesti pasklidusiuose vienuolynų pastatuose nuo XV a., sveikatos priežiūros objektai pradžioje užèmé dalị jų gyvenamųjų patalpų. Vèliau XVI-XVII a. gydymo paslaugos buvo tolydžio perkeliamos ị atskirus vienuolynų pastatus ar jų priskirtas dalis, kur užèmè didžiąją dalị patalpų. XVIII-XIX a. sveikatos priežiūros pastatai palaipsniui prarado glaudų ryši su sakraliniais pastatais, atsiskyrè nuo jų ir tapo nauju viešųjų paslaugų pastato - ligoninès - tipu.

Per raidos šimtmečius sveikatos priežiūros ir gydymo pastatai igavo savo unikalią funkcinę ir erdvinę struktūrą pagal teikiamas paslaugas, kurias pradžioje sudarè atskyrimas, globa bei priežiūra, vèliau - gydymas ir sveikatos priežiūra. Atliktas tyrimas rodo, kad sveikatos priežiūros gydymo pastatams atsiskiriant nuo vienuolynų, keitèsi ir jų funkcinè struktūra. Būdami dalimi sakralinių kompleksų, kuriuos dažniausiai sudarè 
bažnyčia, vienuolynas, gydykla, sodas ar parkas bei kapinès, gydymui naudojami vienuolynų pastatai išsiskyrè Vilniaus siluetuose ir panoramose - jie buvo raiškių „architektūrinių kalvų" dalimi. Šių pastatų grupių išraišką lėmė jų ypatinga erdvinè kompozicija bei architektūrinè raiška.

Sveikatos priežiūros ir gydymo pastatai per visus laikus išlaike itin glaudžius ryšius su vietos bendruomenèmis, teikdami joms socialinę pagalbą ir sveikatos priežiūrą, būdami religijos ir kultūros centrai. Šių pastatų kompleksų istorinès raidos tyrimas yra tvirtas pagrindas, skirtas paremti šiu kompleksų architektūrinès tvarkybos ir municipalinès politikos principams. Šis klausimas yra ypač aktualus šiandieną, kai pradedama radikaliai pertvarkyti sveikatos priežiūros sistemą Lietuvoje ir Vilniaus mieste.

Reikšminiai žodžiai: urbanistinis planavimas, sveikatos priežiūros îstaigų architektūra, socialinè pagalba, siluetas, kraštovaizdis, funkcinè struktūra, kompozicija, ligoninè.

\section{GINTARAS STAUSKIS}

Doctor of the Humanities (arch.), Assoc Prof, Dept of Urban Design, Vilnius Gediminas Technical University (VGTU), Pylimo g. 26/Traku g. 1, 01132 Vilnius, Lithuania.

E-mail: Gintaras.stauskis@vgtu.lt

Participant of European Union research programs since 1998. Research interests: sustainable urban mobility, accessibility of environment, health care networks, recreation and urban health. Research results have been presented in national and international publications and scientific conferences. 